\title{
Teacher's Attitudes Towards the Effects of Lesson Plan on Classroom Management: A Case Study of Sufi Sahab Zakur High School
}

\author{
Mehdi Moradi \\ English Language and Literature Department \\ Education Faculty, Kandahar University \\ Afghanistan \\ E-mail: mehdi.moradiI198@gmail.com
}

\begin{abstract}
The present study has been conducted to investigate the teacher's attitudes towards the effects of lesson plan. Furthermore, the second goal of the study is to investigate the effects of lesson plan on classroom management. Similarly, the questionnaire had two parts the first part had 6 items and the second part had 6 items too and applied randomly. Besides, the data analyzing was performed in SPSS (version, 2I) and bring out the mean and standard division. Finally, the findings reveled the importance and role of lesson planning on classroom management numbered as follow: (I) Planning is the most appropriate skill that the teacher needs to create a successful one. (2) The effective teacher is the one who plan effective lessons. (3) Preparation is the most important thing a teacher does. In addition, the following factors are related to the effects of lesson plan on classroom management. (I) Planning is a necessary skill to develop an organized learning environment. (2) Good planning minimizes class management problems. (3) A successful learning environment is the result of well lesson plan.
\end{abstract}

\section{Keywords: Lesson Plan, Classroom, Effects, Management, Teachers, Attitudes}

\section{Introduction}

Education is crucial to the social, political and economic development of any nation and consequently effective education is very important. Effective teaching is important because it is based on helping children developments from one level to another in a friendlier interactive society and to help students to be independent. Effectiveness does not mean being perfect or giving excellent performances, it is mean being able to plan effective lessons to catch the learner's attention and to get them wholly engaged within the learning process, and consequently no time is available to make noise or bad behaviors in the classroom. For that it has been said that good order is the foundation of all things (Othmane, 2015). Classroom management deals with how things are generally carried out in the classroom. According to Rothstein (2008) classroom management is the relation between the teacher's ability and student's behavior to establish an appropriate classroom learning and teaching. Also Groves (2009) asserted that "classroom management is set of rules, words, and deeds that, the classroom teacher, use to keep classroom running smoothly so that you and your students can work, teach, and learn safely and efficiently".

In addition, teaching is the interaction between teacher and student who participate for getting their own objectives. The quality of the teacher- student relationship is the reason for all other aspects of classroom management, therefore, we may say that the teachers play a major role in planning lesson. When they prepare it effectively, they will have a well-managed classroom since this helps them to avoid discipline problems and to facilitate student learning. Classroom management involves all aspects of what is going on in the classroom while a lesson is being taught because it includes elements of classroom dis cipline but it focuses more on creating learning environment that is organized, engaged and respectful for both teachers and students. (Hanane, 2016). Teachers as well were concerned with the questions of how to teach effectively and how to plan lessons successfully in order to avoid any mistakes with classroom management. Lesson plan as an effective tool of teaching was described by loads of researchers, below are some of them.

\section{Lesson plan}

Hanane (2016) has defined lesson plan as guide for teacher's classroom management that helps teachers to facilitate teaching learning process. The author also explored, lesson plan is an important thing that the teachers should prepare it appropriately before they go to their classes, planning helps teacher to know how to interact with students in easy way. Besides, the author stated lesson plan is the primary technique in teaching, where teacher's ability and knowledge occur in the classroom. According to the writer, lesson planning is the teacher's role in the class to represent his or her experience effectively. Mahon (20II) refers to the lesson plan as, - an organized outline for signal instructional periods, it tells the instructor which teaching method is to 
be used for the lesson, what is to be taught, and in what sequence to present information. Additionally, Edge and Garton (2009) clarify three questions that help the teacher to plan; what are the aims of the lesson? How the teacher is going to achieve these aims? And how will he or she knows if he or she had achieved his or her aims or not? Moreover, Mohan (2007) defined lesson plan as "an outline of the important points of a lesson arranged in the order in which they are to be presented to students by the teacher". In order to facilitate learning for students, the best solution for the teacher is that he or she should prepare his or her lesson.

Similarly, lesson planning is the basic step of classroom management, in a way that a good lesson preparation is a base for a well-managed classroom, for that Butt (2006) claimed that the key to good teaching, purposeful classroom management and the achievement of nonstop educational development occurs in effective lesson planning. Thus, the most effectively the teacher plan his lessons, the classroom will be well managed (Othmane, 2015). In addition, Savage (20I4) described lesson plan is a process of thinking and writing down a plan for teaching and learning within a lesson that I will be teaching to a clear number of students, in a specific place at a specific time. The lesson plan will change over years and also the place and the time may change. Also,

Mishra (2008) reveled that lesson plan is a creative skill of teacher's work which enable him or her to use his or her experience appropriately.

Moreover, Lesson plan is the basic component that the teacher should focus on to describe the lesson because Savage (2014) mentioned that lesson plan is a written document which should be the key of results of teaching and will result in your teaching and your students learning something. Moreover, the author explored that experienced and novice teachers must prepare and plan their lessons before they go to school because it is important and it enables them to avoid many problems.

Although, planning a lesson is an important thing that the teachers should prepare it appropriately before they go to their classes according to Woodward (200I) planning helps you to know how to interact with your students in easy way. Besides that, Neeraja (2003) stated that lesson plan is the primary technique in teaching, where teacher's ability and knowledge occur in the classroom. And according to Lakchmi and Bhaskara (2016) lesson planning is the teacher's role in the class to represent his or her experience effectively. Some teachers may ask themselves why they must make lesson plan before they go to school.

Moreover, Singh (2008) mentioned the need and the importance of lesson plan by many reasons, first, in the teacher's outline, preparing the lesson is the organization of the lesson which facilitates teacher's and student's activities in teaching learning process. Second, lesson plan enables the teachers that what are the goals of the lesson and they will have at less one idea about their subject because every teacher must present his or her practices for achieving the aim of teaching. Third, in lesson planning, an activity should finish the series of the content. Fourth, the ability of the student is focuses on the relation between the new knowledge and the previous knowledge. Fifth, teaching approaches and methods are the most important principles in the content. Sixth, teaching practices and managing the classroom are related with each other. Seventh, lesson plan helps the teacher to respect the sequence of content and in the same time guide him to follow the structure and he or she will not forget his or her ideas and information. Eighth, lesson plan represents an appropriate place for students in the teaching classroom. Ninth, effective lesson plan based on the influence of teacher's role in classroom. Tenth, by creating effective lesson plan the lesson become reachable.

Furthermore, according to the Butt (2006) lesson plan breaks down the activity into steps to decide on arrangement of steps; plan for practice activities, plan for evaluating learning during lesson, the able teachers who have already a clear knowledge about their students who have created a relationship between them and their students and who have clarity about their topics these will help them to understand that they are able to teach an effective lesson. Woodward (2004) proposed that there are some reasons which make the teachers think of having a plan. First, it helps to decrease the feeling of uncertainty or self-doubt and enhancing the teachers sense of confidence and self-sureness, this may reflect on the learners. Moreover, it assisted the teachers to have an idea about the kind of research he is going to conduct. Also, it helps him to think about the materials to use beforehand. Planning lessons and setting goals from the begging would help the students to gather their thoughts about the lesson before class. In addition to that, by planning the teacher would not be confused to answer the learner's questions. Furthermore, it helps the teacher to develop a personal style, and having a permanent record of his work are further advantages of having a plan beforehand.

\section{Statement of the problem}

Lesson plan is one of the most frequent effective factors in the classroom management settings. It has a great influence to manage a good classroom because classes without teacher's planning may lead to discipline problems, disruptive behavior, poor learning, disappointment and frustration. Most of the researchers have the same idea that without lesson plan teachers cannot manage the classroom well which already mentioned in previous pages. Also, a study was conducted by Behzad (2013) reveled that Afghanistan is a developing country which nowadays is experiencing quality education but still there are lots of problems that cause low quality education. Lack of qualified teachers is one of the causes which the majority of school teachers (especially remote areas) are lack of pedagogical content knowledge which in the result they use poor teaching methods. Do not planning a 
lesson is another problem which cause low quality teaching. Lesson plan helps teachers to teach effectively and achieve the goal. Most of Afghan teachers design lesson plan, but have problems in its implementing, in some remote areas the teachers are unaware of designing lesson plan, because most of them are $12^{\text {th }}$ grade graduates.

To respond the above issues and problems this research conducted to explore the use of lesson plan for managing classrooms in Afghanistan primary schools especially at Sufi Sahab Zakur high school and find out the methods of applying lesson plan for managing classrooms better.

\section{Significance of the study}

The ultimate study has a great impact on the learning and teaching process. In order to create a good atmosphere in the classroom, teachers must plan a well-organized lesson. It clarifies the role of lesson planning in improving learners' effective classroom. It will be beneficial for teachers, especially teachers of Sofi Sahab Zakur high school will be able to benefit in their classes.

\section{Purpose of the study}

The present study aims at investigating teacher's role in lesson planning and classroom management. Also it aims at demonstrating the correlation between lesson plan and classroom management as well as to prove that we can eliminate disruptive behavior and to assist teachers to do in which to facilitate teaching learning process. The study emphasizes on planning lesson because it considered being the most necessary component for good classroom. Thus, the role of planning lesson could be link to improve managed classroom style.

\section{Research objectives}

- To investigate teachers' attitudes towards lesson plan at Sufi Sahab Zakur high school.

- To investigate the effects of lesson plan on classroom management at Sufi Sahab Zakur high school.

\section{Research questions}

- What are teacher's attitudes towards lesson plan at Sufi Sahab Zakur high school?

- What are the effects of lesson plan on classroom management at Sufi Sahab Zakur high school?

\section{Literature review}

In this part of study, the author has collected other scholar's findings and results of their studies about effects of lesson plan on classroom management over the world. Historically, and still today researchers and educationalists have debated on the two complex issues of learning and teaching. They have experienced various results and have developed different theories and aspects about learning and teaching. There is no single opinion or definition of learning; every researcher and educationalist have their own views. Learning is often said to be gaining of new knowledge, skills and attitudes (Karlsson and Mansory, 2003).

According to Oser and Baeriswyl, (200I) have conducted a study, the authors revealed that lesson plan is the most important part of teaching, and of improving students learning. This is because it provides teachers with opportunities to plan instructional activities to more effectively meet student's learning needs and to differentiate instruction to enable all students to benefit from instruction.

In addition, through planning, the teacher organizes and structures instructional activities to stimulate the cognitive activation of students. The researchers also argued that through planning teachers are expected to create both the visible structure of a lesson and the deep structure of learning. However, the authors claimed that most teachers organize only the conditions for fixing activities of students over the internal activities of learners. The processes of lesson planning is a complex activity that wants the lesson plan from teachers. First, to design lessons for activating learning by taking into account both learners previous knowledge and learner's motivation. Second, to expect the kind of mental activities to take place when students learn the planned lesson. Third, to plan different kinds and levels of supporting individual students in their learning, and fourth, to plan how to assess the outcomes of implemented instructional plans Oser and Baeriswyl, (200I).

Moreover, the authors proposed four level models of planning for teaching-learning. First, the teachers expect the desired learning outcome and make appropriate lesson plan to achieve the goal of learning. A teacher at this level creates a mental model for focusing on what content should teach and a step-by-step learning strategy. Second, the teacher plans the sequences of teaching (the visible structure of teaching). Third, the teacher plans for sequences of learning (internal learning process) focusing on mental processes of the learner. Fourth, the teacher expects both the cognitive and emotional learning product, and the teacher plans to rate the results of learning products. In summary, the teacher plans for teaching activities, deep learning activities, and evaluation of learning products (Oser and Baeriswyl, 200I).

Jalongo, Rieg, and Helterbran, (2007) stated that lesson plan is an important part of teaching and learning where the teachers make their experience of students learning, and also a lesson plan helps the teacher to select goals, to develop learning activities, and to design appropriate assessments to evaluate and reflect on the outcomes of teaching and learning. 
A quantitative study which explored the use of lesson plans in Afghan primary schools conducted by Behzad (2013), the main objectives of the study were to find out the implementation method of lesson plans, reasons of applying lesson plans and teacher's views on lesson plans. The study conducted in three districts (Shekh Ali, Siah Gerd and Shinwari) and Charikar city of Parwan province and data collected by questionnaires filled in by 200 language and math teachers (I00 males and I00 female). The main findings of the research showed that all teachers regardless of gender, education level and teaching experiences claimed that they used lesson plans in their teaching. A majority of teachers, regardless of gender, education background and years of teaching experience described lesson plans of their own and did not use the format instructed by teachers of Teachers Training Collage. Most teachers prepared their lesson plans one day before at home. To consider the importance of lesson plan stages, the findings showed that the majority of both male and female teachers responded to all stages. Through a short look on reasons of applying lesson plans, the author saw that most of both male and female teachers used lesson plans to achieve the goal. More experienced teachers didn't use lesson plans because of having enough experiences. Important parts of lesson plans include motivation of students and student activities.

Moreover, Courey, Tappe, Siker and LePage, (2012) conducted a research and the authors mentioned the results of their study. The research had several implications for teacher preparation programs. First, credential applicants can benefit from instruction in lesson planning that promotes the use of specific lesson plan techniques and principles to make the general curriculum more accessible to all students. Second, the effect size findings suggest that the lesson planning training maintained over time from the second to third lesson plans and student's use of principles increased as demonstrated by the increase in scores. However, the researchers stated that, in general education settings, the lesson plans can be written so as to provide increased curriculum access for struggling students and their more advanced peers. In this manner, all students in the class may benefit from the variety of instructional and assessment options used by the teachers. The richness of lesson plans with multiple options for representation, action, expression and engagement will probably appeal to students with less skill in class.

Hanane (2016) conducted a research and the researcher explored the relationship between lesson plan and classroom management at the department of English of Mouhamed Khieder University. The researcher tended to know if the teachers see planning as an important part for teaching while student's questionnaire administered to second year students at the department of English in order to know whether the students benefit from teacher's planning or not.

Additionally, the result showed that planning plays a major role to organize and to manage the teacher's classroom. The different answers that the writer has gotten from the participants in questionnaire revealed about some aspects related to their attitude toward the effect of lesson plan on the teacher's classroom management. In addition, their answers supported more the background information which created in this piece of research. Furthermore, the researcher revealed that the importance of planning and preparation makes the teacher more confident for teaching and makes the students aware of learning. Thus, if the researcher considers again the answers of the respondents, the researcher can say that all of the student's attitudes agree with the significance of lesson plan on improving a well-managed classroom because it is a helpful and useful skill for them.

Moreover, as the Hanane (2016) mentioned in section two in the research about lesson plan and its importance and how it can impact on the student's behavior then the results showed that the majority of students are agree with the teacher's planning and preparation. Moreover, the researcher explored about improving an effective classroom management, as the result showed and the questions also dealt with how to make the student's good discipline in the class and the respondents were also present. Last but not least, the researcher stated that from the student's questionnaire results we have found that lesson plan is indeed helpful in managing the teacher's classroom. From the questionnaire results, the researcher has also found that the student's discipline has totally a powerful effect in influencing in the classroom management. Therefore, there is clearly enough evidence to state that if learners follow their teacher's lesson plan, they will create a well-managed teacher's classroom.

However, the researcher also as conclusion mentioned that lesson plan is the most effective skill for both teachers as a detailed outline to teach and students as a detailed guide to learn. All the teachers either experienced or novice one should give more attention to develop an organized classroom environment. If teachers' pay much attention on preparing and planning lessons, it will help the learners too much in increasing their positive discipline, and this lead to create an appropriate classroom management. In addition, the author stated throughout the analysis of the teachers and learner's questionnaires, the following findings were elicited. First, the majority of teachers plan their lessons even if they are experienced. Second, teachers of Ahmed Zeid middle school are aware of the importance of lesson planning for both teachers and learners. Third, lesson planning may effect on classroom management positively or negatively depending on how well it is designed. Fourth, disconnection in the classroom can be reduced by the preparation of lesson plan. Fifth, there is a strong relationship between lesson planning and classroom management.

Sixth, students have a positive attitude toward their teacher's lesson planning. Seventh, teachers of Ahmed Zeid use a few strategies of classroom management in their classrooms.

As well as, in conclusion the author mentioned that effective teaching is based on a good lesson planning because lesson plan is a significant step which allows the teachers to organize their classroom in good way and help the students to concentrate in systematic way since lack of planning lessons may lead to disruptive behavior, frustration, noisy, reduced learning. Therefore, planning is the key or the solution to avoid and eliminate discipline problems in the class as a wellmanaged classroom 
based on an effective lesson plan. According to Mishra (2008) "a good lesson planning is an often invisible by absolutely essential part of all good teaching especially effective language teaching". Thus, effective classroom management is achieved through a well prepared lesson.

Moreover, Othmane (2015) conducted a research, the researcher explored that, teaching is the foundation to provide students with much learning behaviors because improving a well- managed classroom is the responsibility of teachers and schools in which establishes and maintains a good student's discipline in the classroom.

Additionally, it seems from the results that the majority of teachers said never face problems in their classrooms because they plan their lessons in good way, minority of them said rarely face with problems, and few of them said sometimes they face discipline problems.

Furthermore, the majority of students who chose yes that lesson plan is very important for them to create a good understanding while few of them said no it is not important, and some of them said do not know. We want to know whether the students can focus easily when their teachers plan well organized activities.

Moreover, Kř́žzová (2012) conducted a research and the aim of the research was to stress the importance of lesson planning and to prove that openings and endings create essential borders of each lesson. The author stated, in the theoretical part, lesson planning together with openings and endings of lessons were described to create background to the practical part.

For the practical part of the research, the main source of information was the observation sheets of colleagues and own observations. The observation showed interesting results. At nursery and primary schools, songs appeared three times at the beginning of the lesson, checking homework could be found in four observation sheets from nursery to upper secondary schools, only two out of twenty-one teachers used the advance organizer, for example announced the lesson plan at the beginning, this was observed with the learners of lower and upper secondary schools, a game appeared three times as an activity at the beginning with lower and secondary students, there was one case in which homework was set at the center of the lesson, discussion appeared four times with upper secondary and adult learners. However, one observation sheet showed that it was common to use a test at the beginning of the lesson with upper secondary learners. In ten cases, the ends of the lessons included setting homework. In three cases there was a game, the summary or plans for the following lesson. At nursery and lower secondary schools, a song was used in two observed lessons. One lesson ended with a test, one with a discussion and one with a competition (correcting mistakes). It was also discovered that in four cases there was no ending of the lesson and in four cases there was no beginning. The interviews with the teachers proved that most of them do not prepare their lessons in a written form but they know how the lesson should be taught and while teaching, they tried to attach to their previous ideas about the lesson procedure. To summaries, there are many activities which can be included in the beginnings and endings of lessons Kř́žová (2012).

Moreover, the findings of this thesis confirmed that the activities mostly differ according to the age and level of the learners. Thus, all the activities should be different and changed to fit the level of the learners. With young learners, games and songs are more likely to be successful than with more advanced learners. Children learn better through physical activities, drawing and songs. With adults, young adults or teenagers, discussions and presentations seem to be very popular as well as advance organizers and summaries of what has been taught. The writer considered it very useful to investigate lesson planning during the research and to learn about the best practices used in openings and endings of lessons.

\section{Research methods}

Research design

This research design was descriptive quantitative conducted to investigate teacher's attitudes towards the effects of lesson plan on classroom management. According to Creswell (2012) quantitative research attempts to quantity, collect and analyze numerical data, and focus on the links among a smaller number of attribute across many cases.

\section{Site of research}

Sufi Sahab Zakur high school is selected as the data collection source because it is one of the important schools of Kandahar city and also have a huge number of students.

\section{Population and Sampling Size}

In this study, the participants of the study were Sufi

Sahab Zakur high school's teachers. The total of participants in this study were 45 teachers. According to Morgan (1970) table, 40 teachers were randomly selected from that school, among which 20 from morning, 20 from afternoon shift. They were all at the age of 25 to 45 years and with different degree.

\section{Sampling Method}

The method of the research was random sampling and used to develop the sample of the research to figure out the result out by questionnaire, which belongs to the teacher's attitudes towards the effects of lesson plan on classroom management at Sufi Sahab 
Zakur high school in Kandahar city, sample members are selected on the basis of their degree and experience. According to Creswell (2012) in sample random sampling the researcher selects participants for the sample so any individual has an equal probability of being selected from the population. The sample members who were selected had special experience in teaching several subjects. Hence, the researcher provided all 40 teachers of the selected school with the survey questionnaire. The rationale why the researcher has chosen the particular governmental school and the participant is due to their accessibility.

\section{Instrument}

The main instrument used in this research was a questionnaire. The researcher adopted and adapted questionnaire from different studies, such as Hanane (2016) in teacher's questionnaire part, and Othmane (2015) in the analysis of the results part. The questionnaire translated into Pashto language and had three parts: part I: personal information. Part 2: there were 6 items belong to importance of lesson plan. Part 3: there were 6 items belong to effects of lesson plan on classroom management. Based on 5 Likert scales. I: strongly disagree, 2: disagree, 3: somehow agree, 4: agree, 5: strongly agree

\section{Validity and Reliability of the Questionnaire}

Validity refers to the issue of whether the indicator which is introduced to measure the concept, really measures that concept (Denscombe, 2010). On the other hand, the consistency of the findings and conclusion of the research is the basic pillar of the validity (Bryman, 2012). To insure the validity of this research method, before the questionnaire was piloted by the researcher, the author consulted with supervisor for creative feedback and comments. In order to examine the reliability of the questionnaire, the Cronbach's

Alpha method used to evaluate reliability and the researcher used Statistical Package for Social Sciences (SPSS 2I). The reliability of the instrument was calculated .726 which is acceptable.

\section{Data Collection Procedure}

Prior to data collection the researcher sought consent from the head of the faculty. Teachers were also informed of the nature of the study and they were assured that their participation is voluntary and their names would not be reveled in the publication of this research. After seeking the consent of the research participants, the questionnaire was distributed among them and they were directed to fill up the questionnaire in the presence of the researcher. All the research participants were assured that they would be given the access to this study once. All participants responded to the questionnaire and handed over to the researcher.

\section{Data Analysis Procedure}

After collecting the data from participants the data was analyzed in order to know the result of the research that analysis process was held with the help of SPSS software (2I) version in which researcher calculated means, standard deviation to determine the effects of lesson plan on classroom management among the participants.

\section{IO. Findings}

The below table I shows the demographic information of participant in the categories of gender, age, Qualification and Work experience.

Table I: Demographic Information.

\begin{tabular}{|c|c|c|c|}
\hline & Characteristics & No of Participations & Percentage \\
\hline Gender & Male & 40 & $100 \%$ \\
\hline \multirow{12}{*}{$\begin{array}{l}\text { Age of participants } \\
\text { Qualification: } \\
\text { Work experience: }\end{array}$} & $20-15$ & 16 & $40.0 \%$ \\
\hline & $26-30$ & 7 & $17.5 \%$ \\
\hline & $3 I-35$ & 6 & $15.0 \%$ \\
\hline & $36-40$ & 7 & $17.5 \%$ \\
\hline & Graduate & 5 & $\mathrm{I} 2.5 \%$ \\
\hline & Post graduate & II & $27.5 \%$ \\
\hline & License & 24 & $60.0 \%$ \\
\hline & Master & 0 & $0 \%$ \\
\hline & I-5 & 12 & $30.0 \%$ \\
\hline & $6-10$ & II & $27.5 \%$ \\
\hline & II-I5 & 5 & $12.5 \%$ \\
\hline & $16-20$ & 5 & $12.5 \%$ \\
\hline
\end{tabular}


The research questions aimed to finding out what teachers think of planning lessons before going to classroom as well as managing a well-organized classroom?

Table 2: Teacher's attitudes towards the effects of lesson plan.

\begin{tabular}{lcc}
\hline Statement & Mean & SD.DIV \\
\hline Planning is the most appropriate skill that the teacher needs to create a successful one. & 4.85 & $.36 \mathrm{I}$ \\
\hline The effective teacher is the one who plan effective lessons. & 4.82 & .384 \\
\hline Preparation is the most important thing a teacher does. & 4.82 & .384 \\
\hline I face difficulties in preparing a lesson plan. & 4.61 & .633 \\
\hline I have lesson plan for arranging my classroom. & 4.57 & .635 \\
\hline It is important for the teacher to plan his/her lessons. & 4.47 & .933 \\
\hline
\end{tabular}

Likert scales: $\mathrm{I}=$ strongly disagree, $2=$ disagree, $3=$ somehow agree, $4=$ agree and $5=$ strongly agree

The overall finding of the above table shows the effects of lesson plan, the factors with high and low mean are: Planning is the most appropriate skill that the teacher needs to create a successful one. $(\mathrm{M}=4.85$, SD $=.36 \mathrm{I})$, the effective teacher is the one who plan effective lessons. $(M=4.82, \mathrm{SD}=.384)$, Preparation is the most important thing a teacher does. $(\mathrm{M}=4.82, \mathrm{SD}=.384)$, I face difficulties in preparing a lesson plan. $(\mathrm{M}=4.6 \mathrm{I}, \mathrm{SD}=.633)$, I have lesson plan for arranging my classroom. $(\mathrm{M}=4.57, \mathrm{SD}=.635)$. and it is important for the teacher to plan his/her lessons. $(\mathrm{M}=4.47, \mathrm{SD}=.933)$.

Table 3: Effects of lesson plan on teacher's classroom management.

\begin{tabular}{lcc}
\hline Statement & Mean & SD.DIV \\
\hline Planning is a necessary skill to develop an organized learning environment. & 4.77 & .422 \\
\hline Good planning minimizes class management problems. & 4.72 & .452 \\
\hline A successful learning environment is the result of well lesson plan. & 4.70 & .516 \\
\hline Planning lesson is an important part of teaching. & 4.60 & .594 \\
\hline Planning is an easy task to prepare before going to classroom. & 4.57 & .94816 \\
\hline Lesson planning and classroom management have relationship between each other. & 3.13 & I.436 \\
\hline
\end{tabular}

The result of the above table 3 shows the effects of lesson plan on classroom management, the factors with high and low mean are: Planning is a necessary skill to develop an organized learning environment, $(\mathrm{M}=, 4.77$, $\mathrm{SD}=.422)$, Good planning minimizes class management problems, $(M=4.72, \mathrm{SD}=.452)$, a successful learning environment is the result of well lesson plan. $(\mathrm{M}=4.70, \mathrm{SD}=.5 \mathrm{I} 6)$, planning lesson is an important part of teaching, $(\mathrm{M}=4.60, \mathrm{SD}=.594)$, Planning is an easy task to prepare before going to classroom, $(\mathrm{M}=4.57, \mathrm{SD}=.948)$, lesson planning and classroom management have relationship between each other. $(M=3.13$,

$\mathrm{SD}=1.436)$.

\section{Discussion of the results}

In this part of the study, the results have discussed and compared with other studies. After analyzing of the data, the result revealed that the production of well-designed lessons does really influence on classroom management, the teacher's answers show that, the majority of Sufi Sahab Zakur high school teachers apply some strategies of lesson planning and classroom management, but not all of them. This demonstrates that teachers' preparation may affect classroom management positively, the first highest result of the research question; around $90 \%$ of the teachers, education level and teaching experiences responded that they apply lesson plan in their teaching and follow the plan completely or to a large extent. Whether this is true or not, the researcher cannot say, since there was no possibility to follow up the answers by classroom observations. The Ministry of Education of Afghanistan requires individual teachers to use lesson plan in their teaching. Similarly, Tanni (2012) stated that making a lesson plan is necessary and evens the responsibility of teachers in teaching. The second highest result is that, Sufi Sahab Zakur school teachers are wholly alert of the importance of lesson planning in maintaining a healthy learning environment that is free from disruption and management problems but they use a few strategies of lesson planning and classroom management. The remedy to this, is that Sufi Sahab Zakur school teachers have to rethink about designing of lesson plan that have more attractive affects, so that they get their learners more engaged and consequently less disruptive. This is in line with Othmane (2015). 
Furthermore, Hanane (2016) conducted a research, the author collected data from participants and the writer has found from the teacher's questionnaire results that lesson plan is indeed helpful in managing the teacher's classroom. From the questionnaire results, the writer has also found that the student's discipline has exactly a powerful effect in influencing in the classroom management. Therefore, there is clearly enough evidence to state that if learners follow their teacher's lesson plan, they will create a well-managed teacher's classroom.

\section{Conclusion}

Lesson plan is the most effective skill for teachers as a detailed outline to teach. All the teachers either experienced or novice one should give more attention to develop an organized classroom environment. If teachers concentrate much more on preparing and planning lessons, it will help the learners too much in increasing their positive discipline, and this lead to create an appropriate classroom management.

Throughout this research, the researcher has argued that teacher's lesson plan is one major aspect for creating a wellmanaged and organized classroom because this study has covered how to maintain discipline problems for powerful teaching and learning. The aim of recent research in the field is to find the solutions for learning and teaching problems in the class in order to motivate the teachers and to make teaching and learning process more enjoyable. The study starts by exploring the theoretical foundations in which effective teaching cannot occur unless the teachers prepare and plan their lessons in an appropriate way since this research has had an attempt to present how teacher's planning can effect on the student's behavior.

Moreover, the study reports the correlation between lesson plan and classroom management in order to establish a good student's discipline. As the study investigates the relationship between teacher's lesson plan and classroom management, a correlation analysis has been conducted. Teachers questionnaire was correlated the two variables. The results of analysis confirmed the objectives and produced positive results. Finally, teachers should prepare and plan their lessons to create go od student's discipline and pay more attention on how planning can help them to improve an effective classroom management.

\section{Limitation}

The use of quantitative method and questionnaire as data collection tool was a limitation of this study. Use of observation would have been more appropriate or could at least have been used as a complementary method but because of time constraints the researcher could not do that. It is clear that collecting data only from one school with limited number of teachers may not be very representative to all schools in the country and the results cannot be generalizable. Due to security problems, lack of transportation, long distance and time constraints only one school in the Kandahar city of the province was selected for this study. The fact that the respondents were mainly from the selected school could also account as a limitation. Cultural problems like difficulties of contacting with teachers were also the limitation of the current study.

\section{References}

Behzad, A., (2013). Method and system of lesson planning in classroom environment. U.S. Patent No. 8,442,015. Washington, DC: U.S. Patent and Trademark Office.

Bryman, A, (2012) Social Research methods. Oxford: Oxford University Press. Butt,G.(2006). Lesson planning. London and New York: Continuim international publishing.

Courey, S. J., Tappe, P., Siker, J., \& LePage, P. (2012). Teacher Education and Special. Teacher Education and Special Education, 36(I), 7-27.

Creswell, J. W., (2012). Planning, Conducting, and Evaluating Quantitative and Qualitative Research. Sage publication. Denscombe, M. (2010). The Good Research Guide for small-scale research projects. Milton Kenynes: Open University Press.

Groves,E.(2009). The everything classroom management book: a teacher's guide to an organized, productive, and calm classroom. United State: Adams media.

Hamilton, L., Halverson, R., Jackson, S., Mandinach, E., Supovitz, J., \& Wayman, J. (2009). Using student achievement data to support instructional decision making (NCEE 20094067). Washington, DC: National Center for Education Evaluation and Regional Assistance, Institute of Education Sciences, U.S. Department of Education.

Hanane, T., (2016). The Effects of Lesson Plan on Teacher's Classroom Management; Case study: Second Year English Students of LMD at Biskra University.

Karlsson, P. \&Mansory, A. (2003), WESTERN LEARNING, Theories of Learning, Stockholm: Stockholm University

Kř́řzová, B. (2012). Openings and Closures of English Lessons. Mishra,L.(2008). Teaching of mathematics. India: A P H publishing corporation.

Mohan,R.(2007). Innovative science teaching: for physical science teachers.Delhi: P H I learning private limited (3ed).

Neeraja,K.(2003). Text book of nursing education. New Delhi: Jaypee brother's medical publishers.

Oser, F., \& Baeriswyl, F. (200I). Choreographies of teachings. Bridging Instruction to Learning. In V.Richardson (Ed.), Choreographies of teachings. Bridging Instruktion to Learning (4th ed., pp. I03 I-I085). Washington: American Educational Research Association. 
Othmane, M..(2015). The Role of Lesson Planning in Improving EffectiveClassroom Management. The Case of Middle School Teachers of English at Ahmed Zeid - Biskra.

Rothstein, C. and Trumbull, F. (2008). Managing divers' classrooms: How to build on student cultural strengths (p. 02). USA: association for Supervision and Curriculum Development

Singh, Y. (2008). Teaching of English (p. I87). India: APA Publishing Corporation.

Tanni, M. (2012), Teacher Trainees' Information Acquisition in Lesson planning, iR information research, Vol. I7: No.3

Woodward, T. (2004). Planning lessons and courses (pp. I,I6,233,234,235). United Kingdom: Cambridge university press.

\section{Copyrights}

Copyright for this article is retained by the author(s), with first publication rights granted to the journal. This is an open-access article distributed under the terms and conditions of the Creative Commons Attribution license (http://creativecommons.org/licenses/by/4.0/). 